\title{
Mineralogical and isotopic characterization of graphite deposits from the Anatectic Complex of Toledo, central Spain
}

\author{
Iván Martín-Méndez ${ }^{1}$, Ester Boixereu ${ }^{1}$, Carlos Villaseca² \\ ${ }^{1}$ Instituto Geológico y Minero de España, Madrid, España, i.martin@igme.es, e.boixereu@igme.es \\ ${ }^{2}$ Dpto. Petrología y Geoquímica, Facultad Geología, Instituto de Geociencias IGEO (UCM, CSIC), Madrid, \\ España, granito@ucm.es \\ Corresponding author: Iván Martín Méndez, i.martin@igme.es
}

\begin{abstract}
Graphite is found dispersed in high-grade metapelitic rocks of the Anatectic Complex of Toledo (ACT) and was mined during the mid twentieth century in places where it has been concentrated (Guadamur and la Puebla de Montalbán mines). Some samples from these mines show variable but significant alteration intensity, reaching very low-T hydrothermal (supergene) conditions for some samples from the waste heap of the Guadamur site $\left(<100{ }^{\circ} \mathrm{C}\right.$ and $\left.1 \mathrm{kbar}\right)$. Micro-Raman and XRD data indicate that all the studied ACT graphite is of high crystallinity irrespectively of the degree of hydrothermal alteration. Chemical differences were obtained for graphite $\delta^{13} \mathrm{C}$ composition. ACT granulitic graphite shows $\delta^{13} \mathrm{C}_{\mathrm{PDB}}$ values in the range of -20.5 to $-27.8 \%$, indicating a biogenic origin. Interaction of graphite with hydrothermal fluids does not modify isotopic compositions even in the most transformed samples from mining sites. The different isotopic signatures of graphite from the mining sites reflect its contrasted primary carbon source. The high crystallinity of studied graphite makes this area of central Spain suitable for graphitic exploration and its potential exploitation, due to the low carbon content required for its viability and its strategic applications in advanced technologies, such as graphene synthesis.
\end{abstract}

Key words: Graphite, XRD, Raman spectra, carbon isotopes, Variscan granulites 
Graphite is primarily found in metamorphic rocks although it can appear in other geological settings. There are four common types of graphite in nature: i) graphite formed through metamorphism of biogenic carbonaceous material, ii) mantle-derived graphite, iii) graphite formed as precipitates from aqueous fluids and iv) graphite formed through reduction of carbonates (e.g., Luque et al. 1998; Galvez et al. 2013).

Graphite is considered a critical mineral due to its low abundance in nature and because it is a strategic material for the manufacturing of electronic devices, as lubricant, as a cathode for Li-ion batteries and is commonly used in nanotechnology. It is expected that the demand for graphite will increase approximately a 4\% in the coming years (e.g., Lazzeri and Barreiro 2014).

Graphite deposits are scarce in the world. The main graphite deposits in the world are in metamorphic terrains like those in Orissa state in India and the Precambrian Granulitic Complex of Wanni in Sri Lanka (Luque et al. 2014), although there are other deposits in China, Brazil, Mexico and Madagascar (Beyssac and Rumble 2014). In Spain, the main deposits are in Málaga (Ronda peridotites, where graphite is associated with sulphides in ultramafic rocks) (Luque et al. 1992; Crespo et al. 2006a), Huelva (Almonaster la Real, Cortegana, Aroche and Santa Ana la Real, where graphite is present in high-grade metamorphic rocks) (Rodas et al. 2000; Crespo et al. 2004), Segovia (El Muyo, Madriguera, Becerril and Ayllón, where graphite and carbonaceous material are associated with black shales) (Barrenechea et al. 1991) and the Toledo anatectic complex (Luque et al. 1992; IGME 1995).

In this paper we document graphite occurrences within the "Anatectic Complex of Toledo" (ACT) which is located in the Central Iberian Zone of the Variscan Belt. Graphite is an accessory mineral present in most of the metasedimentary-derived rocks from this high-grade anatectic complex. Moreover, two graphite deposits that were previously mined in the twentieth century appear in this zone: the Guadamur and "La Española" (la Puebla de Montalbán) mines. Graphite in metasedimentary rocks usually has a biogenic origin and is formed by the change of organic carbonaceous material in sediments due to metamorphic processes (Buseck and Beyssac 2014). Graphite deposits are mainly 
associated with high- and medium-grade metamorphic rocks like the granulite-facies rocks found in the ACT. As graphite is not incorporated into the melt fraction of a partial melting process, is considered a melting residue (e.g, Cesare and Maineri 1999). The amount of graphite in metamorphosed metasedimentary rock depends greatly on the metamorphic degree and the melting fraction underwent during anatexis in granulite-facies rocks.

The aim of this work is to characterize the graphite from granulitic rocks and from mined areas of la Puebla de Montalbán and Guadamur sites and to compare the ordered and high temperature graphite (in granulites) from the graphite that appears in more hydrothermally affected areas (in mines). In the la Puebla de Montalbán area some graphite is locally concentrated along late micro shear bands. The common association of graphite to highly deformed metamorphic rocks and the combined roles of deformation processes and fluid percolation for graphite deposition during late stages of granulite terrane exhumation are key factors in the study of ACT graphite deposits. Thus, we have analyzed the graphite crystallinity using X-ray diffractometry (XRD) and micro-Raman spectroscopy. Carbon isotopes have been performed to study the origin of the carbon sources and the possible role of hydrothermal fluids in local graphite remobilization. Pressure-temperature conditions of graphite crystallization and re-equilibration have been estimated from mineral paragenesis in each of the two mined areas. To our knowledge this is the first study devoted to the ACT graphite from the first graphite producing area in Spain, and probably its largest and most strategically important reservoir of this ore due to its highly ordered structure.

\section{Geological setting}

The Anatectic Complex of Toledo (ACT) is located to the south of Toledo city and occupies an area of around $100 \mathrm{~km}^{2}$ (Fig. 1). The southern limit is defined by a mylonitic zone, a late-Variscan ductile normal fault with listric geometry (Toledo shear zone). This fault separates the anatecticgranulitic complex from Paleozoic to Neoproterozoic low grade metasedimentary rocks of the southern Schist Greywacke Complex (Aparicio 1971; Barbero 1992; Barbero and Villaseca 2004). The 
northern limit is delimitated by a set of E-W-trending alpine faults, that separate high grade rocks of the ACT from Cenozoic sediments of the Tagus basin (Fig. 1).

The ACT is a high-grade metamorphic terrane located in the inner areas of the Central Iberian Zone. The high-grade metamorphism of the ACT is of Variscan age (around 314 to $310 \mathrm{Ma}$, Barbero and Rogers 1999 by monazite U-Pb dating; Castiñeiras et al. 2008 by zircon U-Pb dating). Three main groups of rocks have been distinguished in the ACT (Barbero 1995; Barbero and Villaseca 2004) (Fig. 1): (1) High-grade metamorphic rocks of two types: (a) granulite-facies pelitic metasedimentary rocks with complex migmatite structures, interlayered with semi-pelitic sediments and minor quartzites, calc-silicate rocks and marbles; (b) orthogneisses of felsic composition, mainly augen-gneisses and leucogneisses. (2) Highly to moderately peraluminous granitoids of anatectic character, ranging from restite-rich varieties (e.g., Layos type, Barbero and Villaseca 1992) to anatectical leucogranites (e.g., Cervatos type, Barbero et al. 1995). Most of these peraluminous suites are interpreted as having been generated during Variscan anatexis of ACT materials (Barbero 1992; Barbero et al. 1995). (3) Intrusive calc-alkaline granitoids (Argés type) and associated basic rocks that were emplaced synorogenically during the Variscan metamorphic climax and underwent the granulite-facies migmatization.

The metamorphic peak conditions of the ACT were estimated to be $800 \pm 50{ }^{\circ} \mathrm{C}$ and $4-6 \mathrm{kbar}$ followed by a retrograde cooling recorded by garnet rim conditions at broader conditions of 600 to 700 ${ }^{\circ} \mathrm{C}$ and below 3 kbar (Barbero, 1995). The study of non-aqueous fluid inclusions in ACT migmatites indicates that at those mid-T conditions of $550{ }^{\circ} \mathrm{C}$, the ACT was exhumed to pressures below $1 \mathrm{kbar}$ (Martín Romera et al. 2001).

Peraluminous granulites and migmatites are the most abundant metamorphic rocks in the complex and the main host of graphite in the ACT. The granulites can have migmatitic banding or massive granoblastic texture and are interpreted as residual rocks after granite melt extraction (Barbero 1995; Barbero et al. 1995). Graphite is a common accessory mineral in these residual granulites.

Two graphite-rich sectors in the ACT were mined: La Puebla de Montalbán (La Española exploitation), and the Guadamur mine. The la Española and Guadamur mines were exploited berween 
1939 and 1961, being the main producers of graphite in Spain at that time. The la Española graphite deposit is located to the north of Gálvez (Fig. 1), and was mined from 1943 to 1947, producing around 530 tonnes of graphite. In 1946 the mine was closed due to transport problems and the plant was moved to Guadamur (Sánchez Ronda 2013). The Guadamur mines were active until 1961 in two periods of time; the first from 1919 to 1920 when 310 tonnes of graphite was obtained, and the second from 1947 to 1961 producing 4500 tonnes). These graphite mines were the last ones exploited in Spain.

Some samples from Guadamur mines were boulders taken from tailing deposits and waste heaps as the underground excavations had collapsed and were covered for safety (samples 114432, 114433, 114434). Additional sampling was taken from trenches and neighbor areas. Samples from the La Puebla de Montalbán area were taken from the surroundings and local excavations. In the latter case some graphite-rich bands are concentrated by late extensional micro-shears with orientations of N11040NE to N135-50NE (Fig. 2).

\section{Analytical methods}

Two types of graphite were sampled for this study: (1) granulitic graphite of the ACT and from one granulite xenolith from the lower crust of the Spanish Central System (SCS) in central Spain (sample U-10 from Villaseca et al. 1999), (2) graphite from the two mined sites.

Major-element mineral compositions were determined at the Centro Nacional de Microscopía Electrónica "Luis Bru" (Universidad Complutense de Madrid) using a Jeol JXA-8900 M electron microprobe with five wavelength dispersive spectrometers. Analytical conditions were an accelerating voltage of $15 \mathrm{kV}$ and an electron beam current of $20 \mathrm{nA}$, with a beam diameter of $5 \mu \mathrm{m}$. Elements were counted for $10 \mathrm{~s}$ on the peak and $5 \mathrm{~s}$ on each background position. Corrections were made using the ZAF method. Analytical precision is $0.5-6 \%$ for oxides with concentrations $>0.5 \mathrm{wt} \%$ whereas those with contents $<0.5 \mathrm{wt} \%$ have uncertainties close to $10 \%$. Results are reported in Table 1.

Graphite-rich samples from granulites and mining areas were analyzed using a Bruker D8 Advance X-ray diffractometer (DRX) at the CAI Técnicas Geológicas of the Universidad 
Complutense of Madrid with $\mathrm{CuK \alpha}(40 \mathrm{kV}, 40 \mathrm{~mA})$ radiation. The $2 \theta$ values of the obtained peaks were calibrated using an internal corundum standard. The thickness of $\operatorname{Lc}(002)$ was calculated using the Scherrer equation (Scherrer 1918). DRX were also used for volumetric analysis (wt\% of C) and semiquantitative mineral estimation. Data processing was performed using DIFFRAC.Suite Eva diffraction/xrd-software/overview/eva.html). Samples analysed and results are reported in Table 2.

A concentrated carbon-rich fraction of samples from mining areas was prepared in the IGME laboratories, at Tres Cantos (Madrid), before submitting to isotope analyses. This was done using $\mathrm{HCl}$ and HF acid dissolution to remove silicate and carbonate minerals. In addition, graphite from granulite samples was separated using standard mineral separation techniques and handpicking. Carbon stable isotope analyses of graphite were done in the Stable Isotope Laboratories of the University of Salamanca. The determination of isotope ${ }^{13} \mathrm{C} /{ }^{12} \mathrm{C}$ ratios in graphite was performed by combustion in an elemental analyzer EA3000 Eurovector coupled online to a mass spectrometer Isoprime (TM) in "continuous flow". The results (the mean value of triplicate analysis \pm 1 standard deviation) are reported in $\delta \%$ relative to the PDB standard for carbon. Laboratory machine standard $\mathrm{CO}_{2}$ gas measurements gave reproducibility better than $0.1 \%$.

Micro-Raman analyses were done in the laboratories of the Museo Nacional de Ciencias Naturales de Madrid (CSIC). Raman spectra were collected on unpolished rock chip surfaces to avoid damage from polishing (e.g., Pasteris 1989; Beyssac et al. 2003). A $532 \mathrm{~nm}$ wavelength beam from a 5-10 mW laser was focused on Thermo Fischer CRX microscope using 50x or 100x objectives for the analysis. Under these conditions the spectral resolution was $2-4 \mathrm{~cm}^{-1}$ and the spectral range was $100-2900 \mathrm{~cm}^{-1}$. The laser beam size was approximately 2 microns. Integration times were between 10 and 16 seconds for each acquisition. The final spectrum and mean value for each sample were obtained by summing 3 to 5 spectra acquired under the same operating conditions. No significant changes were observed in the second order Raman region of graphite, and thus the study focused on the first order Raman spectra $\left(1100-1800 \mathrm{~cm}^{-1}\right)$. Data processing was performed by LabSpec software v.5.33.14, obtaining parameters derived from each spectrum by deconvoluting gaussian-lorentzian peaks. 
Graphite is mostly disseminated in the ACT samples, and its exploitation was focused in granulitic bands showing anomalous concentration of graphite-rich flakes. Graphite is an accessory mineral in the granulites, and is normally associated to biotite or other high-grade metamorphic minerals as garnet, sillimanite, cordierite, plagioclase, quartz or K-feldspar (Fig. 3a,b). Biotite is observed in granulites next to the mines associated to graphite. The composition of biotite crystals is similar to samples analyzed by Barbero et al. (1992) (Table 1). The modal amount of graphite is usually low in the high-grade metasedimentary rocks of the ACT, either in migmatites or as residual granulites $(<0.5 \%)$, but in areas close to both mining sites some granulite-facies rocks with graphiterich cm-size bands can reach concentrations up to 23 vol.\% (Table 2) (Fig. 2).

In mining areas (at least in the best outcropping mine of the La Puebla de Montalbán) most of the exploited graphite was related to granulitic graphite-rich bands, whereas minor amount of graphite was extracted from late micro-shear bands associated to retrograded muscovite. Samples from the Guadamur site were more altered and original field relationships are more difficult to establish due to poor outcropping conditions. In all samples shape of graphite is flaky and is forming small lamellae between the phyllosilicates. The coarsest flakes are those from granulites (up to $450 \mu \mathrm{m}$ ), whereas it is around $150-250 \mu \mathrm{m}$ in some Guadamur rubble (tailing) samples (Fig. 3f).

In the Guadamur mining zones muscovite is the most abundant mica clearly suggesting retrograde conditions. Most of the granulitic minerals are retrograded except quartz and some biotite not completely transformed to chlorite. Muscovite and chlorite crystals are usually associated with disseminated graphite suggesting local pseudomorphosis of pre-existing biotite and total feldspar retrogression by water-rich metasomatism (Fig. 3c,d).

Chlorites appear only in some of the Guadamur samples (Fig. 3d) (Table 2), indicating more intense retrogradation conditions than in the La Puebla de Montalbán area. It appears as interlayered flakes associated with graphite suggesting total transformation of previous micas (granulitic biotite 
and secondary muscovite). Chemically they are ripidiolite to picnoclhorite (Table 1). In one sample

192

193

194

195

196

197

198

199

200

201

202

203

204

205

206

207

208

209

210

211

212

213

214

215

216

217 from Guadamur (114432) an extremely low-grade mineral paragenesis associated to graphite and quartz was found: this is formed by kaolinite-goethite-jarosite. Kaolinite is found only in this waste heap sample associated to black and metallic luster flakes of graphite, showing that graphite-rich samples from Guadamur have been more retrograded than those from La Puebla de Montalbán mines (Fig. 3e). Jarosite is the only sulfate found in Guadamur samples. Jarosite is associated with goethite forming oxidation bands in that sample (Fig. 3f). This sulfate is formed at very low temperature, around $100{ }^{\circ} \mathrm{C}$, by supergene alteration (Peters 2011). Moreover, Fe-rich hydroxides are abundant in samples from Guadamur area suggesting significant either supergene or hydrothermal fluid alteration. Goethite, the more abundant hydroxide, appears forming alternating bands with jarosite in rubble samples. Associated to goethite another Fe-hydroxide rich in $\mathrm{Si}$ and $\mathrm{Al}$, which might be chamosite (James 1966) was also present in some samples (Fig. 3g) (Table 1).

Calcite was found in the two mining areas in hydrothermally retrograded samples, usually forming veins or brecciated rocks. In all cases, carbonate appears in two scenarios: (1) forming intrusive small veins or a network of veinlettes (Fig. 3h,i), never related to graphite flakes, (2) as brecciated rocks with calcite cement within granulitic (variably transformed) fragments (Fig. 3g), always indicating that carbonate percolation is a later hydrothermal stage. In Guadamur area, calcite is forming veins with accessory aragonite in zoned vugs (geodes) (Fig. 3i).

Samples from Guadamur contain ilmenite crystals with alteration rims to anatase (Table 1 sample 114434). On the other hand, samples from La Puebla de Montalbán contain ilmenite partially transformed to a titanium oxide with significant contents of $\mathrm{SiO}_{2}$ (up to $23 \mathrm{wt} \%$ ) and $\mathrm{Al}_{2} \mathrm{O}_{3}(23 \mathrm{wt} \%$ ) (Table 1), that could be pseudorutile (Fig. 3j). Pseudorutile is commonly originated by ilmenite alteration and can also be variably hydroxylated (up to 10-12 wt\% $\mathrm{H}_{2} \mathrm{O}$ ) (Grey and $\mathrm{Li} 2003$ ). The most transformed ilmenites are hydroxylated pseudorutiles (HSR phases) with low $\mathrm{FeO}$ and high $\mathrm{H}_{2} \mathrm{O}$ contents (up to $25 \mathrm{wt} \%$ ) (Table 1). These data suggest that granulitic ilmenite have been variably altered by hydrothermal fluid circulation in the samples from ACT mined areas. The most hydroxylated pseudorutiles suggest hydrothermal low temperature conditions $\left(150-260{ }^{\circ} \mathrm{C}\right)$ as 
described by Grey et al. (1983). Accessory pyrite could appear in some granulites, usually transformed to hematite when retrograded.

In summary, ACT graphite is associated to minerals formed in three growth stages: (1) a primary stage in while the graphite accompanies anhydrous granulitic minerals, (2) a retrograde stage in which graphite is associated with hydrous minerals such as muscovite and chlorite, and (3) an oxide/weathering stage in which the graphite is associated with jarosite, goethite and kaolinite (mainly restricted to waste heap samples from Guadamur site).

\section{Graphite characterization}

\section{$X R D$ and micro-Raman spectroscopy}

To obtain high quality data of graphite from XRD studies is very difficult due to the low absorption coefficient of carbon. This problem can lead to errors associated to the displacement of the main peak of the spectrum. To obtain better results, this survey focused on the analysis of the 002 peak, that shows the greatest intensity in well ordered graphite (Baiju et al. 2005). Moreover, carbon contents were firstly determined in samples without chemical pre-concentration treatment (Table 2). The data confirms that Guadamur samples have slightly more carbon (or graphite) contents (up to 24 wt $\%$ ) than those from La Puebla de Montalbán (up to 20 wt\%).

The full-width of the peak at half maximum values and $d$ and $2 \theta$ position were estimated from the diffractogram (Baiju et al. 2005). The crystal size (Lc) along stacking direction (Table 2) is calculated from the next equation:

$L c_{(002)}=k \lambda / \beta_{(002)} \cos \theta$

Where $\mathrm{k}$ is the shape constant (0.94), $\beta_{(002)}$ is the full width of the peak at half-maximum in radian and $\lambda$ is the $\mathrm{X}$-ray wavelength in angstroms (1.5406). and $\theta$ is the angle of diffraction in radians. The high $\operatorname{Lc}(002)$ values found in all ACT samples (> 800) suggest a highly crystalline graphite phase irrespectively of its association to high-T or low-T phyllosilicates ( Table 2). 
Similarly, the Raman spectrum of graphite is very sensitive to changes in crystallinity (e.g.,

Pasteris and Wotapenka 1991; Wotapenka and Pasteris 1993).There are two main regions of interest in graphite Raman spectrum. The first one occurs between 1100 and $1800 \mathrm{~cm}^{-1}$ and the second one between 2500 and $3100 \mathrm{~cm}^{-1}$, called the first order spectrum and second order spectrum, respectively (Cesare and Maineri 1999; Beyssac et al. 2002). The most important characteristics in graphite Raman spectrum are: the $\mathrm{G}$ peak that appears approximately at $1580 \mathrm{~cm}^{-1}$ (ordered graphite), the $\mathrm{D}$ and $\mathrm{D}_{0}$ peaks around 1350 and $1620 \mathrm{~cm}^{-1}$ (disordered graphite) and the $\mathrm{S}$ peak around $2700 \mathrm{~cm}^{-1}$ (Beyssac and Lazzeri 2012).

Raman spectra of samples collected from late retrograded micro-shears in Galvez area show a $\mathrm{G}$ peak in a position around $1580 \mathrm{~cm}^{-1}$ with a significant height difference with the $\mathrm{D}$ peak, around $1350 \mathrm{~cm}^{-1}$ (Fig. 4). This height difference (R2 values in Table 2) has been usually interpreted as a reflection of high ordered graphite. Spectra from U-10 and ACT granulites are very similar to those of La Puebla de Montalbán (Table 2). Graphite from Guadamur samples show spectra identical to the previously described. In these spectra the G peak is very pronounced and a small D peak appears in some determinations as typically found in highly ordered graphite (Cesare and Maineri 1999). Moreover, graphite spectra obtained from the Guadamur sample with kaolinite and jarosite, is also similar to the other ACT samples due to the high crystallinity of this phase, clearly not structurally affected by hydrothermal fluid circulation (Fig. 4).

\section{Carbon isotopic composition}

Graphite appears disseminated in different ACT rocks: (a) as an accessory mineral in granulites, (b) concentrated in local $\mathrm{cm}$-size bands in granulites in the surroundings of the mining areas, (c) in strongly hydrothermally altered rocks, locally with carbonate veined samples or breccias, in the Guadamur mining area. To evaluate the evolution pattern of isotopic composition and a possible source of carbon we have analyzed the $\delta^{13} \mathrm{C}$ of samples from the different areas described above, as well as in a UHT granulitic xenolith from the lower crust of the neighbor Spanish Central System (U10 granulite of Villaseca et al. 1999). There are three potentials sources of carbon: (1) devolatilization 
of carbonaceous metapelites, (2) mantle-derived and (3) decarbonation of carbonate rocks (e.g., Luque et al. 1998; Barrenechea et al. 2009).

Three different graphite types in the ACT were clearly distinguished on the basis of the carbon isotope results (Table 2). (1) the values of $\delta^{13} \mathrm{C}_{\mathrm{PDB}}$ of -18.3 to $-19.7 \%$, obtained from U-10 sample, indicate an organic origin of carbon. Carbon isotope values from the ACT granulites define a wide range between -20.5 to $-27.8 \%$, also indicating a biogenic carbon source. The highest ACT values are close to those of the lower crustal granulites from central Spain, in spite of the difference in P-T metamorphic conditions (Fig. 5). Values from graphite-rich a granulites from La Puebla de Montalbán range from -20.5 to $-23.4 \%$, a range of values that include those found in samples from the neighbor mining site (-23.0 to $-23.2 \%$, Table 2). Finally, a restricted range of $\delta^{13} \mathrm{C}_{\mathrm{PDB}}(-27.6$ to $-27.9 \%$, Table 2) indicates that Guadamur mining site samples have the lowest carbon isotope values, although such ligth values are also found in regional granulitic material (Table 2). In summary, graphite samples from mining areas show a remarkable narrow isotopic compositional range that, nevertheless, is always found in the surrounding granulitic rocks. A carbonate sample from an intrusive vein in strongly hydrothermalized rocks of the Guadamur site yields a $\delta^{13} \mathrm{C}_{\mathrm{PDB}}$ value of -5.15 (Table 2), in the typical range of carbonates (e.g., Luque et al. 2012), and similar to values found in hydrothermal carbonates of the Neoproterozoic metamorphic series of central Spain (Herrero et al. 2011).

\section{Thermometric estimation of retrograded graphite-rich samples based on mineral paragenesis}

$P-T$ estimations of retrograded ACT samples have been mainly achieved by paragenetic relations between graphite and surrounding phyllosilicates, mainly biotite, muscovite, chlorite and kaolinite (Fig. 6).

As previously described, the ACT underwent a metamorphic peak around $800 \pm 50{ }^{\circ} \mathrm{C}$ and $4-6$ kbar and later suffered a retrogradation event with temperature below $700{ }^{\circ} \mathrm{C}$ and pressure decreasing to 2 kbar (data obtained from P-T estimations using garnet rims) (Barbero 1995) (Fig. 6). Furthermore, 
data obtained in fluid inclusions in quartz from granulites show a later exhumation stage in the ACT, to pressures lower than $1 \mathrm{kbar}$ and temperatures around $600{ }^{\circ} \mathrm{C}$ for the highest-T carbonic inclusions (Martín Romera et al. 2001). This fluid inclusions study describes an evolution from $\mathrm{CO}_{2}$-rich fluids (close to post-peak conditions) towards mixed $\mathrm{CO}_{2}-\mathrm{N}_{2}-\mathrm{CH}_{4}$-rich fluids, and later low temperature nonaqueous $\mathrm{N}_{2}-\mathrm{CH}_{4}$-rich inclusions associated to aqueous fluid inclusions (at $<200^{\circ} \mathrm{C}$ ). The presence of common accessory graphite within the granulite matrix suggests that it was equilibrated during granulite metamorphism at very low volatile conditions (Barbero 1995).

Low-temperature minerals associated to graphite observed in this study allow us to define three different retrograde stages (Fig. 6). The first one is related to the muscovite recrystallization at around $500{ }^{\circ} \mathrm{C}$, the second stage could be related to the occurrence of chlorite, around $400{ }^{\circ} \mathrm{C}$, and the third stage explain the occurrence of kaolinite at temperatures below $300{ }^{\circ} \mathrm{C}$ probably of supergene conditions and related to surface weathering (Fig. 6). These three stages experienced very little variations of pressure, (i.e., $\leq 1$ kbar), according to data from fluid inclusions (Martín Romera et al. 2001).

Different $P-T$ conditions derived by paragenetic assemblages were observed by comparing La Puebla de Montalbán and Guadamur graphite-rich samples. La Puebla de Montalbán graphite-bearing samples may have biotite or biotite plus muscovite (Fig. 6 stage 1), whereas in the Guadamur samples graphite is associated with muscovite, chlorite and also kaolinite. Moreover, jarosite was only found in the kaolinite-bearing sample from Guadamur, which is a supergene alteration mineral formed near to surface, indicating the most recent alteration with temperatures $<100{ }^{\circ} \mathrm{C}$. We can conclude that temperatures recorded by retrograded phyllosilicate formation from La Puebla de Montalbán are higher than those from Guadamur area (Fig. 6 stages 2 and 3).

Graphite formed at granulitic conditions interacted with hydrothermal fluids when the granulitic high-T minerals were completely transformed to new low- $\mathrm{T}$ and $\mathrm{H}_{2} \mathrm{O}$-rich phases, being this retrogradation more effective in local micro-domains (late shear bands or brittle vein systems) occurring in studied mining areas. Nevertheless, the refractive character of graphite permits the 
conservation of its high crystallinity also maintaining its chemical composition due to the sluggish diffusion kinetics of graphite with fluids (Wada 1988), as will be discussed below.

\section{High crystallinity of the ACT graphite}

The accessory graphite found in the studied high-T granulites of central Spain is highly crystalline. Estimated temperature of granulite formation range from circa $1000{ }^{\circ} \mathrm{C}$ in central Spain lower crustal granulitic xenoliths (e.g., Orejana et al. 2010) to $800{ }^{\circ} \mathrm{C}$ in the ACT granulite terrane (Barbero 1995). Graphite with full-ordered structure mostly appears in granulite rocks formed at $>700$ ${ }^{\circ} \mathrm{C}$ (e.g., Pasteris and Wopenka 1991; Baiju et al. 2005). The graphite of the lower crustal xenolith U10 has Raman R2 ratios of 0.11 and XRD d(002) values (3.354, Table 2), typical of high grade metamorphic graphite (e.g., Shengelia et al. 1979; Wopenka and Pasteris 1993; Beyssac et al. 2002). Similarly, ACT granulites have graphite with R2 and d(002) values of 0.08 to 0.12 and 3.354 to 3.365 , respectively (Table 2). Sample 114568 from La Puebla de Montalbán, which is affected by a microshear band (Fig. 2b), has, unexpectedly, the lowest crystallinity values of the whole data set (Table 2), with lower Raman and XRD parameters than those found in pervasively hydrothermallized and mylonitized samples from ACT mining areas. Nevertheless, graphite from this granulite is in the range of well-ordered structural features.

The graphite from the strongly hydrothermalized samples from the Guadamur mines has the same high degree of crystallinity when compared with the graphite in the nearby granulite rocks (Table 2). This is shown by comparing the Raman parameter R1 (Intensity D band/Intensity G band) in Guadamur graphite that range from 0.001 to 0.10 whereas the $\mathrm{G}$ band FWHM changes broadening from 15.06 to 16.07 (Table 2). Moreover, most Raman spectra have a humped S peak around $2700 \mathrm{~cm}^{-}$

${ }^{1}$ (Fig. 4), typical of high-T graphite (e.g., Beyssac et al. 2002). Using XRD data, the Lc(002) of the graphite varies from 879 to $1200 \AA$ A (Table 2) typical of high crystallinity (e.g., Shengelia et al. 1979; Baiju et al. 2005; Nakamura et al. 2014). 

Puebla de Montalbán mining area), but there is no evidence of significant graphite concentration with deformation, as those samples that have low modal graphite (2.2 to $7.8 \mathrm{wt} \%$, samples 114554 to 114558 in Table 2) are clearly shifted to the lower part of the range of modal graphite within

351 disseminated flakes in the surrounding granulites (1.5 to $20.1 \mathrm{wt} \%$, Table 2). Moreover, the graphite in micro shear bands of La Puebla de Montalbán mine has the same well-ordered structure as the associated granulites without size reduction. This suggests that graphite structure during deformation towards low-T conditions in both mining areas of the ACT terrane was not associated with a lowering in crystallinity when compared to other granulitic areas. A simple explanation could be that graphite concentration in the ACT deposits is locally controlled by physical remobilization of pre-existing disseminated graphite and is not related to precipitation from hydrothermal fluids. Moreover, graphite related to these strongly hydrothermallized areas is not isotopically modified respect to the original granulitic graphite, as will be discussed in the next section.

The high crystallinity of studied graphite makes central Spain graphite suitable for applications in advanced technologies, as graphene synthesis. A previous work on metamorphic graphite in central Spain, on rocks from the eastern Spanish Central System, yielded Raman features of low crystallinity ( R2 values of 0.8 or higher, Table 1 of Crespo et al. 2005) suggesting that only in high-grade areas (at granulite-facies conditions) rich in metasedimentary rocks of pelitic derivation, as those occurring at the studied ACT, are the most strategic areas for graphite exploration and exploitation for commercial viability (e.g., Beyssac and Rumble 2014).

\section{Source of carbon}

Isotopic $\delta^{13} \mathrm{C}$ data are normally used to determine the source of carbon within the three main crustal existing reservoirs, which are characterized by different isotopic $\delta^{13} \mathrm{C}$ values. Carbon from organic material ranges from -20 to $-30 \%$, whereas carbon from carbonated sources has values close to $0 \%$. In contrast, carbon from mantle sources has values around -7 \%o (e.g., Sanyal et al. 2009; 
Touzain et al. 2010). As samples from this study have values between -20 and $-30 \%$, we infer that carbon in the ACT rocks has an organic origin.

Isotopic data from high-temperature granulites of the area (i.e., U-10 sample with $\delta^{13} \mathrm{C}$ values around $-19 \%$ and ACT granulites around -20.5 to $-27.8 \%$ (Table 2)), are indicative of the original graphite, as these samples were not significantly affected by alteration or hydrothermal fluids. The high variability in $\delta^{13} \mathrm{C}$ signatures of the ACT granulites is representative of the carbon isotopic heterogeneity of the primary organic material trapped in the original metasediments.

Carbon isotopic composition from samples of mining sites are quite different between them but showing very uniform values within each deposit site $(-23.1 \%$ o \pm 0.1 in the La Puebla de Montalbán, and $-27.6 \% \pm 0.2$ in Guadamur mines), values that are also found in the wide range of $\delta^{13} \mathrm{C}$ signatures of the surrounding granulites. Moreover, the remarkable homogeneity of carbon isotope values of samples in each ACT mine suggest a lack of open system evolution during their hydrothermal alteration and suggest the absence of significant chemical fractionation during fluid interaction. Because of the retrograded low temperature conditions, the activation energy might not have crossed the threshold necessary to precipitate the graphite or to trigger carbon isotope exchange with percolating fluids. The carbon isotopic data implies a refractory character of the ACT graphite. The deformed and retrograded graphite in the mining sites was not formed by precipitation from fluids and was not chemically modified within the hydrothermal veining, and instead the results point just to the physical remobilization of graphite during later retrograde events. The graphite in the mining areas was converted from well-structured graphite into small fractured graphite (e.g., Fig. 3g), with its carbon isotopic composition unchanged.

The absence of heavy $\delta^{13} \mathrm{C}$ isotope values in the ACT samples is indicative of the absence of a fluid precipitated origin for the graphite, and also indicates the lack of interaction with later carbonate fluids, which show much heavier carbon isotope composition $(-5.2 \%$, Table 2$)$. The uniform $\delta^{13} \mathrm{C}$ values of samples from ACT mines is indicative that retrograding and weathering processes have not had a significant effect on their isotopic characteristics. 

pressures, and in similar pressure conditions at higher temperatures. This could take place during peak

401

402

403

404

405 and post-peak metamorphic conditions when the ACT was mainly exhumed to low pressure conditions (Barbero, 1992). The decompression of the ACT and its slow cooling, combined with natural deformation and fluid circulation focused in late micro-shears or hydrothermal veins were factors that failed to induce any chemical change of the ACT graphite or its recrystallization towards lower crystallinity types (or amorphous varieties of smaller size). General features of the granulitic graphite were maintained irrespectively of their alteration degree or mechanical deformation. This refractory character increases the resources and possibilities of mining and production of the ACT graphite for future processing and uses.

\section{Conclusions}

Graphite is found dispersed in many of the ACT rocks but it was mined in places where a greater concentration of black flakes appeared (Guadamur and La Puebla de Montalbán mines). In these mine pits, graphite was locally concentrated within late shear bands.

Micro-Raman and XRD data allow us to establish that all the studied ACT graphite is of high crystallinity irrespective of the hydrothermal degree of alteration of the sample. Thus, the ACT graphite is of high-temperature and refractory to structural changes during low-T fluid interaction. A trend in retrogradation conditions was observed in our study, reaching very low-T hydrothermal conditions some of the waste heap samples from the Guadamur mine site $\left(<100{ }^{\circ} \mathrm{C}\right.$ and $\left.1 \mathrm{kbar}\right)$. The maintenance of high crystallinity in all studied samples indicates that graphite concentration in the ACT deposits is controlled by physical remobilization of pre-existing disseminated graphite and is not related to precipitation from hydrothermal fluids.

Chemical differences were obtained for graphite $\delta^{13} \mathrm{C}$ composition. ACT granulites show $\delta^{13} \mathrm{C}_{\mathrm{PDB}}$ values between -20.5 to $-27.8 \%$ reflecting the primary carbon isotopic heterogeneity of the organic material. $\delta^{13} \mathrm{C}$ constant values have been found in samples from both mining sites $(-23.1 \%$ \pm 
0.1 in the La Puebla de Montalbán, and $-27.6 \% \pm 0.2$ in Guadamur), overlapping the wide range of $\delta^{13} \mathrm{C}$ signatures of the surrounding granulites. This suggests a lack of carbon isotope exchange with

427

428

429 hydrothermal fluids. Thus, graphite in the mining sites was not formed by precipitation from fluids but was physically remobilized during later retrograde events. This graphite was converted from wellstructured graphite into small fractured graphite, with its carbon isotopic composition unchanged.

The high crystallinity of studied graphite makes ACT graphite suitable for exploration and exploitation, due to the low carbon content required for its commercial viability and strategic applications in advanced technologies, as graphene synthesis.

\section{Acknowledgements}

We acknowledge Alfredo Fernández Larios for his assistance with the electron microprobe analyses in the Centro Nacional de Microscopía Electrónica (UCM), and to Alberto Jorge García for his microRaman assistance in the Museo de Ciencias Naturales (CSIC). We also thanks to Xavier Arroyo Rey (CAI-DRX-UCM), and Jesús Reyes and Begoña del Moral from the analytical laboratories of the IGME their technical assistance. We thanks also to Jesús López Jerez for offering his sampling of granulites and graphite-rich rocks around mining areas of the ACT. We would like to especially thank Maite García Vallés for her assistance in Raman data processing. We also thank to Clemente Recio for his diligence in performing $\mathrm{C}$ isotope analyses in the Stable Isotope Laboratory of the Salamanca University. This work is included in the objectives of, and supported by, the CGL2012-32822 project of the Ministerio de Economía y Competitividad of Spain, and the 910492-UCM group. Finally, this study will be included in the metallogenetic database of the IGME.

\section{References}

Aparicio A (1971) Estudio geológico del Macizo Cristalino de Toledo. Est Geol 27: 361-414. 
Baiju KR, Satish-Kumar M, Kagi H, Nambiar CG, Ravinsankar M. (2005) Mineralogical characterization of graphite deposits from Thodupuzha-Kanjirappally Belt, Madurai Granulite Block, Southern India. Gond Res 8: 223-230.

Barbero L (1992) Plutonismo sin-orogénico en un área granulítica Hercínica: El Complejo Anatéctico de Toledo. Doctoral dissertation. University Complutense of Madrid

Barbero L (1995) Granulite-facies metamorphism in the Anatectic Complex of Toledo, Spain: late Hercynian tectonic evolution by crustal extension. J Geol Soc London 152: 365-382.

Barbero L, Rogers G (1999) Implications of U-Pb monazite ages from synorogenic granites of the anatectic complex of Toledo (Spain) in the evolution of the central part of the Hercynian Iberian Belt. Doc BRGM 290: 203.

Barbero L, Villaseca C (1992) The Layos granite, Hercynian Complex of Toledo (Spain): an example of parautochthonous restite-rich granite in a granulitic area. Trans Roy Soc Edinburgh: Earth Sci 83: 127-138.

Barbero L, Villaseca C, Rogers G, Brown P (1995) Geochemical and isotopic disequilibrium in crustal melting: An insight from the anatectic granitoids from Toledo, Spain. J Geoph Res 100: 15745-15765.

Barbero L, Villaseca C (2004) El macizo de Toledo. In: Vera JA (ed) Geología de Geología de España, SGEIGME, Madrid, pp 110-115.

Barrenechea JF, Luque FJ, Millward D, Ortega L, Beyssac O, Rodas M (2009) Graphite morphologies from the Borrowdale deposit (NW England, UK): Raman and SIMS data. Contr Mineral Petrol 158: 37-51.

Beyssac O, Coffé B, Chopin C, Rouzaud J N (2002) Raman spectra of carbonaceous material in metasediments: a new geothermometer. J Metam Geol 20: 859-871.

Beyssac O, Goffé B, Petitet JP, Froigneux E, Moreau M, Rouzaud JN (2003) On the characterization of disordered and heterogeneous carbonaceous materials by Raman spectroscopy. Spectrochimica acta part A: Molecular and biomolecular spectroscopy 59: 2267-2276.

Beyssac O, Lazzeri M (2012) Application of raman spectroscopy to the study of graphitic carbons in the earth sciences. European Mineralogical Union Notes in Mineralogy 12: 451-454. 
Beyssac O, Rumble D (2014) Graphitic carbon: a ubiquitous, diverse, and useful geomaterial. Elements 10: 415420.

Buseck PR, Beyssac O (2014) Graphitic carbon: From organic matter to graphite: Graphitization. Elements 10: 421-426.

Castiñeiras P, Villaseca C, Barbero L, Martín Romera C (2008) SHRIMP U-Pb zircon dating of anatexis in highgrade migmatite complexes of Central Spain: implications in the Hercynian evolution of Central Iberia. Int J Earth Sci 98: 1609-1624.

Cesare B, Maineri C (1999) Fluid-present anatexis of metapelites at El Joyazo (SE Spain): constraints from Raman spectroscopy of graphite. Contr Mineral Petrol 134: 41-52.

Crespo E, Luque J, Fernández-Rodríguez C, Rodas M, Díaz-Azpiroz M, Fernández-Caliani JC, Barrenechea JF (2004) Significance of graphite occurrence in the Aracena Metamorphic Belt, Iberian Massif. Geol Mag 141: $687-697$.

Crespo E, Luque J, Barrenechea JF, Rodas M (2005) Mechanical graphite transport in fault zones and the formation of graphite veins. Mineral Mag 69: 463-470.

Crespo E, Luque J. Rodas M, Wada H, Gervilla F (2006a) Graphite-sulfide deposits in Ronda and Beni Bousera peridotites (Spain and Morocco) and the origin of carbon in mantle-derived rocks. Gond Res 9: 279-290.

Crespo E, Luque J, Barrenechea FJ, Rodas M (2006b) Influence of grinding on graphite crystallinity from experimental and natural data: implications for graphite thermometry and sample preparation. Mineral Mag 70: $697-707$.

Gálvez ME, Beyssac O, Martinez I, Benzerara K, Chaduteau C, Malvosin B, Malavieille J (2013) Graphite formation by carbonate reduction during subduction. Nature Geoscience 6: 473-477.

Grey IE, Li C, Watts, JA (1983). Hydrothermal synthesis of goethite-rutile intergrowth structures and their relationship to pseudorutile American Mineral 68: 981-988Grey IE, Li C (2003) Hidroxylian pseudorutile derived from picroilmenite in the Murray Basin, Southeastern Australia. Mineral Mag 67: 733-747. 
Herrero MJ, Martín-Pérez A, Alonso-Zarza AM, Gil-Peña I, Meléndez A, Martín García R (2011) Petrography and geochemistry of the magnesites and dolostones of the Ediacaran Ibor Group (635 to $542 \mathrm{Ma}$ ), Western Spain: Evidences of their hydrothermal origin. Sedim Geol 240: 71-84.

IGME (1995). Exploración del grafito en España. Centro de Documentación IGME, nº 11415, (unpublished document) Madrid.

James HL (1966) Chemistry of the iron-rich sedimentary rocks. Data of Geochemistry, Geol Survey Prof Paper 440, $66 \mathrm{pp}$

Kretz R (1983) Symbols for rock-forming minerals. Amer Mineral 68: 277-279.

Lazzeri M, Barreiro A (2014) Graphitic carbon: carbon-based nanoscience. Elements 10: 447-452.

Luque FJ, Rodas M, Barrenechea JM, Galán Huertos E (1992) Yacimientos españoles de grafito. In: García Guinea J, Martínez Frías J (ed) Recursos minerales de España, CSIC, Madrid, 501-524.

Luque F.J, Pasteris JD, Wotapenka B, Rodas M, Barrenechea F (1998) Natural fluid-deposited graphite: Mineralogical characteristics and mechanism of formation. Amer J Sci 298: 471-498.

Luque FJ, Crespo-Feo E, Barrenechea JF, Ortega L (2012) Carbon isotopes of graphite: Implications on fluid history. Geos Frontiers 3: 197-207.

Luque FJ, Huizenga JM, Crespo E, Wada H, Ortega L, Barrenechea JF (2014) Vein graphite deposits: geological setting, origin and economic significance. Miner Deposita 49: 261-277.

Martín Parra LM, Gutiérrez Alonso G, Sánchez Carretero R, Contreras López E, Jorquera de Guindos A, Gracia Prieto FJ (2009) Mapa Geológico de España a escala 1:50.000, hoja nº 656 (Gálvez), IGME, Madrid.

Manning CE, Shock EL, Sverjensky DA (2013) The chemistry of carbon in aqueous fluids at crustal and uppermantle conditions: experimental and theoretical constraints. Rev MineralGeochem 75: 109-148.

Martín Romera C, Villaseca C, López-García JA, Boiron MC, Barbero L (2001) $\mathrm{CO}_{2}-\mathrm{CH}_{4}-\mathrm{N}_{2}$ Fluid inclusions in granulite-facies migmatites of hercynian anatectic complexes of central Spain. XVI ECROFI, 287-289. 
Nair AG, Suresh Babu DS, Domodaran KT, Shankar R, Prabhu CN (2009) Weathering of ilmenite from Chavara deposit and its comparison with Manavalakurichi placer ilmenite, southwestern India. J Asian Earth Sci 34: 115-122.

Nakamura Y, Ooashi K, Toyoshima T, Satish-Kumar M, Akai J (2014) Strain-induced amorphization of graphite in fault zones of the Hidaka metamorphic belt, Hokkaido, Japan. J Struct Geol doi: 10.1016/j.jsg.2014.10.012

Orejana D, Villaseca C, Armstrom RA, Jeffries TE (2010) Geochronology and trace element chemistry of zircon and garnet from granulite xenoliths: Constraints on the tectonothermal evolution of the lower crust under central Spain. Lithos 124: 103-116.

Pasteris JD (1989) In Situ Analysis in Geological Thin-Sections by Laser Raman Microprobe Spectroscopy: A Cautionary Note. Applied Spectroscoy 43: 567-570

Pasteris JD, Wopenka B (1991) Raman spectra of graphite as indicators of degree of metamorphism. Canadian Mineralogist 29: 1-9.

Peters D (2011) Mineralogical and chemical characterization of alunita group minerals from hydrothermal veins of the Sultana mineralization/SE Spain. Dissertation, Johanes Gutenber-University Mainz, Institute of Geosciences.

Pimienta MA, Dresselhaus G, Dresselhaus MS, Cançado LG, Jorio A, Saito R (2007) Studying disorder in graphite-based systems by Raman spectroscopy. Phys Chem Chem Physics 9: 1276-1291.

Rodas M, Luque FJ, Barrenechea JF, Fernández-Caliani JC, Miras A, Fernández-Rodríguez C (2000). Graphite occurrences in the low-pressure/high-temperature metamorphic belt of Sierra de Aracena (southern Iberian Massif). Mineralogical Magazine 64: 801-814

Rumble D (2014) Hydrothermal graphitic carbon. Elements 10: 427-433.

Sánchez Carretero R, Contreras López E, Martín Parra L, Martínez-Salanova J, Gutiérrez Alonso G, Barbero L, Villaseca C (2009) Mapa geológico de España 1: 50 000, hoja nº 657 (Sonseca), IGME, Madrid 
Sánchez Ronda D (2013) Una aproximación a las nuevas formas alotrópicas del carbono y al beneficio del grafito en la provincia de Toledo. Graduate Dissertation, Universidad Politécnica, Almadén. 224 pp.

Sanyal P, Acharya BC, Bhattacharya SK, Sarkar A, Agrawal S, Bera MK (2009) Origin of graphite, and temperature of metamorphism in Precambrian Eastern Ghats Mobile Belt, Orissa, India: A carbon isotope approach. J Asian Earth Sci 36: 252-260.

Scherrer P (1918) Bestimmung der grösse un der inneren struktur von kolloidteilchen mittels Röngntgenstrahlen, nachrichten von der gesellschaft der wissenschaften, Göttingen Mathem Physik Klasse 2: 98-100.

Shengelia DM, Akhvlediani RA, Ketskhoveli DN (1979) The graphite geothermometer. Dobkl. Acad. Nauk. USSR 235: 132-134.

Spear FS (1993) Metamorphic Phase Equilibria and Pressure-Temperature-Time Paths. Mineralogical Society of America Monograph, Washington.

Touzain P, Balasooriya N, Bandaranayake K, Descolas-Gros C (2010) Vein graphite from the Bogala and Kahatacha-Kolongaha Mines, Sri-Lanka: A possible origin. Canad Mineral 48: 1373-1384.

Villaseca C, Downes H, Pin C, Barbero L (1999) Nature and composition of the lower continental crust in Central Spain and the granulite-granite linkage: interferences from granulitic xenoliths. J Petrol 40: 14651496.

Villaseca C, Merino E, Oyarzun R, Orejana D, Pérez-Soba C, Chicharro E (2014) Contrasting chemical and isotopic signatures from Neoproterozoic metasediments in the Central-Iberian Zone of pre-Variscan Europe (Spain): implications for terrane analysis and early Ordovician magmatic belts. Precam Res 245: 131-145.

Wada H (1988) Microscale isotopic zoning in calcite and graphite crystals in marble. Nature 331: 61-63.

Wopenka B, Pasteris JD (1993) Structural characterization of kerogens to granulite-facies graphite: Applicability of Raman microprobe spectroscopy. Amer Mineral 78: 533-557. 
571 Figure 1 - Geological map of the ACT (based on Barbero 19992; Barbero and Villaseca 2004; Martín

572

573

574

575

576

577

578

579

580

581

582

583

584

585

586

587

588

589

590

591

592

593 Parra et al. 2009; Sánchez-Carretero et al. 2009). To the south of the Toledo shear band outcrop late-Variscan granites and Paleozoic and Neoproterozoic metasedimentary sequences most of them included in the Schist-Greywacke Formation (SGF) from the southern Central Iberian Zone (see Villaseca et al. 2014, and references therein).

Figure 2 - Occurrences of graphite-bearing rocks in La Puebla de Montalbán mine site. (a) Parallel late shear micro bands with local concentration of graphite, in a mining pit (samples 114554, 114555 and 114556). (b) Micro shears affecting a graphite-rich granulite (sample 114568).

Figure 3 - BSE microphotographs illustrating graphite textures. Guadamur site: (a) Graphite prisms within granulitic minerals (sillimanite, quartz, ilmenite) (sample 114423). (b) Photomicrograph taken under plane-polarized light. Graphite flakes within quartz in granulite (sample 114400). (c) Graphite within muscovite and sericitized plagioclase, with accessory ilmenite (sample 114434). (d) Graphite within muscovite, chlorite, and associated goethite (sample 114431). (e) Graphite within kaolinite and numerous rounded goethite crystals in the upper left quadrant (sample 114432). (f) Tailing rock with jarosite- and goethite-banding, showing interstitial micropholded grphite (sample 114432). (g) Microfolded graphite with associated goethite-chamosite in a calcite-bearing breccia (sample 114427). (h) Calcite veins within altered graphite-bearing rock (sample 114635). (i) Calcite veins with accessory aragonite in vugs (geodes) (sample 114635). La Puebla de Montalbán site: (j) Graphite flakes interstitial to pseudorutile, quartz and K-feldspar crystals (granulite sample 114568). Symbols: $\mathrm{Gr}=$ graphite, Sil= sillimanite, $\mathrm{Ilm}=$ ilmenite, $\mathrm{Qtz}=$ quartz, $\mathrm{Ms}=$ muscovite, $\mathrm{Pl}=$ plagioclase, $\mathrm{Chl}=$ chlorite, $\mathrm{Gt}=$ goethite, $\mathrm{Kln}=$ kaolinite, $\mathrm{Jar}=$ jarosite, $\mathrm{Chm}=$ chamosite, $\mathrm{Cal}=$ calcite, $\mathrm{Arg}=$ aragonite, $\mathrm{Psrt}=$ pseudorutile, $\mathrm{Kf}=\mathrm{K}$-feldspar $($ after Kretz 1983). 
Figure 4 - Examples of Raman spectra of the well-ordered ACT graphite. (a) Spectra of high R1 and R2 Raman parameters (sample 114568 from La Puebla de Montalbán), (b) Spectra of highly crystalline graphite in a highly retrograded sample form the Guadamur mine site (tailing 114432)

Figure 5 - Histogram plot of the graphite $\delta^{13} \mathrm{C}$ composition from the ACT. The carbon isotope data show three isotopic groups of biogenic carbon sources.

Figure 6 - Summary of $P$-T conditions of graphite-bearing rocks from the ACT plotted together averaged P-T estimates of the high-grade conditions of the ACT from Barbero $(1992,1995)$. Estimates for $\mathrm{CO}_{2}$-rich fluid inclusions (FI) taken from Martín Romera et al. (2001). Petrogenetic grid for phyllosilicates in pelitic rocks is taken from Spear (1993).

Figure 7 - Relationships between stable carbon isotope results and estimated temperature of retrogradation of graphite-bearing rocks in the mining sites of the ACT. Averaged P-T estimates of the high-grade conditions of the ACT from Barbero $(1992,1995)$, and for sample U-10 from the lower crust of central Spain, from Villaseca et al. (1999). Carbon isotope data from dolostones of the Schist Greywacke Complex (with $\delta^{13} \mathrm{C}$ from -4.4 to $+3.2 \%$ ) is taken from Herrero et al. (2011) and biogenic sources (including hydrothermal $\mathrm{H}_{2} \mathrm{O}-\mathrm{NH}_{4}$-rich fluids) is taken from Luque et al. (2012). 
612

613 Table 1 - Representative mineral composition (EMP data) of the ACT samples

614 Table 2 - Summary of chemical and structural (XRD and Raman spectroscopy) features of 615 graphite in the ACT

616

617

618

619

620

621

622

623

624 
Table 1. Representative mineral composition (EPMA data) of the ACT samples

\begin{tabular}{|c|c|c|c|c|c|c|c|c|c|c|c|c|c|c|c|c|c|c|}
\hline Mineral & $\mathrm{Bt}$ & Ms & Ms & Ms & Ms & Ms & Chl & Chl & Kln & Gt & $\mathrm{Chm}$ & Jar & $\mathrm{Ilm}$ & Ant & Ps-Rt & Ps-Rt & HSR & HSR \\
\hline $\begin{array}{l}\text { Sample } \\
\text { Location }\end{array}$ & $\begin{array}{c}114570 \\
\text { Granulite } \\
\text { Montalbán }\end{array}$ & $\begin{array}{c}114429 \\
\text { Guadamur } \\
\text { mine }\end{array}$ & $\begin{array}{c}114434 \\
\text { Guadamur } \\
\text { mine }\end{array}$ & $\begin{array}{c}114431 \\
\text { Guadamur } \\
\text { mine }\end{array}$ & $\begin{array}{c}114557 \\
\text { Montalbán } \\
\text { mine }\end{array}$ & $\begin{array}{c}114638 \\
\text { Montalbán } \\
\text { mine }\end{array}$ & $\begin{array}{c}114431 \\
\text { Guadamur } \\
\text { mine }\end{array}$ & $\begin{array}{c}114635 \\
\text { Guadamur } \\
\text { mine }\end{array}$ & $\begin{array}{c}114432 \\
\text { Guadamur } \\
\text { mine }\end{array}$ & $\begin{array}{c}114432 \\
\text { Guadamur } \\
\text { mine }\end{array}$ & $\begin{array}{c}114427 \\
\text { Guadamur } \\
\text { mine }\end{array}$ & $\begin{array}{c}114432 \\
\text { Guadamur } \\
\text { mine }\end{array}$ & $\begin{array}{c}114434 \\
\text { Guadamur } \\
\text { mine }\end{array}$ & $\begin{array}{c}114434 \\
\text { Guadamur } \\
\text { mine }\end{array}$ & $\begin{array}{c}114568 \\
\text { Granulite } \\
\text { Montalbán }\end{array}$ & $\begin{array}{c}114568 \\
\text { Granulite } \\
\text { Montalbán }\end{array}$ & $\begin{array}{c}114569 \\
\text { Montalbán } \\
\text { mine }\end{array}$ & $\begin{array}{c}114569 \\
\text { Montalbán } \\
\text { mine }\end{array}$ \\
\hline Analysis & 14.2 & 12.1 & 28.1 & 32.1 & 19.2 & 35.2 & 35.1 & 28.2 & 21.1 & 24.1 & 40.1 & 18.1 & 30.1 & 31.1 & 9.2 & 10.2 & 1.2 & 6.2 \\
\hline $\mathrm{SiO}_{2}$ & 34.73 & 45.72 & 44.38 & 44.83 & 45.13 & 45.32 & 26.32 & 25.60 & 46.08 & 1.64 & 20.26 & 1.15 & 1.38 & 0.28 & 0.50 & 2.38 & 1.91 & 5.72 \\
\hline $\mathrm{TiO}_{2}$ & 4.83 & 0.09 & 0.11 & 0.23 & 0.38 & 0.02 & & 0.22 & 0.02 & & & 0.02 & 55.20 & 93.45 & 61.30 & 59.09 & 75.09 & 74.56 \\
\hline $\mathrm{Al}_{2} \mathrm{O}_{3}$ & 18.57 & 35.62 & 35.01 & 33.14 & 35.83 & 36.41 & 22.48 & 21.30 & 37.55 & 3.33 & 10.75 & 4.05 & 0.84 & 0.40 & 0.93 & 1.52 & & 4.93 \\
\hline $\mathrm{FeO}$ & 19.80 & 1.33 & 1.43 & 2.04 & 0.10 & 0.69 & 25.01 & 25.85 & 0.51 & 69.95 & 44.30 & 36.51 & 35.31 & 3.70 & 29.24 & 27.89 & 13.61 & 8.33 \\
\hline MnO & 0.07 & 0.05 & & & 0.01 & 0.02 & 0.17 & 0.06 & 0.01 & 0.11 & 0.03 & & 0.92 & & 0.09 & 0.04 & 0.01 & 0.04 \\
\hline MgO & 7.32 & 0.05 & 0.67 & 1.03 & 0.32 & 0.09 & 11.51 & 10.35 & 0.05 & & 1.02 & 0.01 & 0.09 & & 0.25 & 0.27 & & 1.21 \\
\hline $\mathrm{CaO}$ & & 0.03 & 0.04 & 0.01 & 0.11 & 0.02 & 0.38 & 0.09 & 0.12 & 0.31 & 0.85 & 0.06 & 0.05 & 0.12 & 0.53 & 0.60 & & 0.54 \\
\hline $\mathrm{Na}_{2} \mathrm{O}$ & 0.19 & 0.27 & 0.59 & 0.62 & 0.62 & 0.43 & & 0.01 & 0.03 & 0.06 & 0.02 & 0.07 & 0.04 & 0.02 & 0.01 & 0.01 & & 0.02 \\
\hline $\mathbf{K}_{2} \mathbf{O}$ & 8.89 & 9.86 & 10.08 & 9.54 & 10.14 & 9.92 & 0.30 & 0.15 & 0.04 & 0.03 & 0.81 & 8.20 & 0.12 & 0.03 & & & & \\
\hline $\mathbf{P}_{2} \mathbf{O}_{5}$ & 0.01 & & & & & & 0.01 & & & 1.68 & 0.52 & 0.02 & 0.03 & 0.07 & 0.18 & 0.18 & 0.03 & 0.02 \\
\hline $\mathrm{ZnO}$ & & & & & & & & & & 0.12 & 0.19 & & 0.69 & 0.08 & & & & \\
\hline $\mathrm{Cr}_{2} \mathrm{O}_{3}$ & 0.12 & & & & & & & 0.29 & & & & & & & 0.08 & 0.13 & 0.05 & 0.07 \\
\hline $\mathrm{SO}_{3}$ & & & & & & & & & & 0.56 & 0.11 & 29.31 & & 0.05 & 0.01 & & 0.01 & \\
\hline Total & 94.75 & 93.09 & 92.46 & 91.60 & 93.58 & 92.92 & 86.90 & 84.00 & 84.49 & 77.82 & 78.89 & 79.77 & 94.51 & 98.18 & 93.37 & 92.49 & 90.95 & 95.71 \\
\hline
\end{tabular}

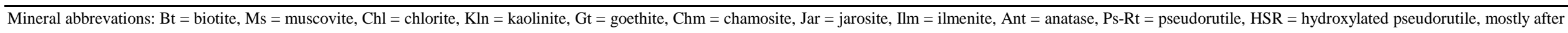
Kretz (1983). Blank rows are data below detection limits. 
Table 2 - Summary of isotopic and structural (XRD and Raman spectroscopy) features of graphite in the ACT

\begin{tabular}{|c|c|c|c|c|c|c|c|c|c|c|c|c|c|c|c|}
\hline \multirow[t]{2}{*}{ Sample } & \multirow[t]{2}{*}{ Locality } & \multirow[t]{2}{*}{ Lithology } & \multirow[t]{2}{*}{ Mineral association } & \multirow{2}{*}{$\begin{array}{c}\text { Alteration } \\
\text { intensity } \\
\end{array}$} & \multirow{2}{*}{$\begin{array}{l}\delta^{13} \mathbf{C} \\
(\% 0) \\
\end{array}$} & \multirow[t]{2}{*}{ $\pm 1 \sigma$} & \multirow[t]{2}{*}{$\begin{array}{c}\text { graphite } \\
(\%)\end{array}$} & \multicolumn{2}{|c|}{ XRD results } & \multicolumn{6}{|c|}{ Raman results } \\
\hline & & & & & & & & $2 \theta$ & $\begin{array}{l}d(002) \\
(\mathrm{A}) \\
\end{array}$ & $\begin{array}{l}\text { FWHM } \\
(2 \theta) \\
\end{array}$ & $\begin{array}{l}\text { Lc (002) } \\
\text { (A) }\end{array}$ & $\begin{array}{c}\mathrm{G} \\
\text { position }\end{array}$ & $\begin{array}{l}\text { G-FWHM } \\
\left(\mathrm{cm}^{-1}\right) \\
\end{array}$ & R1 & R2 \\
\hline & & & High-T rocks & & & & & & & & & & & & \\
\hline U-10 & SCS lower crust & Granulite & Qtz-Grt-Sil-Pl-Rt & - & -18.28 & 0.29 & & & & & & & & & \\
\hline $\mathrm{U}-10$ & SCS lower crust & Granulite & Qtz-Grt-Sil-Pl-Rt & - & -19.70 & 0.19 & $0.5^{*}$ & 26.56 & 3.354 & n.d. & & 1580 & 15.33 & 0.04 & 0.11 \\
\hline 114400 & Guadamur & Granulite & Qtz-Pl-Bt-Grt-Ilm & - & -20.59 & 0.09 & $0.2 *$ & 26.55 & 3.354 & n.d. & & 1580 & 16.46 & 0.05 & 0.12 \\
\hline 114632 & Guadamur & Granulite & Sil-Qtz-Ilm-Alt & med & -27.76 & 0.07 & $23.5^{*}$ & & & & & & & & \\
\hline 114633 & Guadamur & Granulite & Qtz-(PI-Kf)-Bt-Grt-Sil-Ilm & med & -20.92 & 0.01 & $21.2^{*}$ & & & & & & & & \\
\hline 114568 & P. Montalbán mine & Sheared granulite & Qtz-Pl-Kf-Bt-Sil-Grt-(Crd)-Ilm & low & -20.91 & 0.06 & $9.5^{*}$ & 26.47 & 3.365 & 0.104 & 820 & 1580 & 18.64 & 0.12 & 0.22 \\
\hline 114571 & Puebla Montalbán & Granulite & Qtz-Pl-Kf-Bt-Sil-Grt-(Crd)-Ilm & med & -23.38 & 0.03 & $20.1 *$ & 26.48 & 3.363 & 0.076 & 1120 & 1581 & 16.34 & 0.03 & 0.08 \\
\hline 114566 & Puebla Montalbán & Granulite & Qtz-Crd-Kf-Sil-Pl-Bt-Grt-Ilm & - & -20.58 & 0.16 & $2.8^{*}$ & & & & & & & & \\
\hline \multirow[t]{2}{*}{114567} & Puebla Montalbán & Granulite & Qtz-Pl-Kf-Bt-Sil-Grt-(Crd)-Ilm & low & -20.46 & 0.06 & $1.5^{*}$ & & & & & & & & \\
\hline & & & Mid-to-low-T rocks & & & & & & & & & & & & \\
\hline 114428 & Guadamur mine site & Retrograded rock & Qtz-Pl-Ms-Chm-Alt & high & -27.63 & 0.12 & 12.3 & 26.52 & 3.359 & 0.085 & 1000 & 1579 & 15.06 & 0.00 & 0.03 \\
\hline 114429 & Guadamur mine site & Retrograded rock & Qtz-Pl-Ms-Chm-Gt-Alt & high & -27.86 & 0.03 & 10.2 & 26.50 & 3.362 & 0.089 & 958 & 1580 & 14.64 & 0.02 & 0.05 \\
\hline 114430 & Guadamur mine site & Retrograded rock & Qtz-Pl-Ms-Chm-Gt-Cal-Alt & high & -27.86 & 0.12 & 10.0 & 26.52 & 3.358 & 0.082 & 1040 & & & & \\
\hline 114431 & Guadamur mine (trench) & Retrograded rock & Qtz-(Bt)-Ms-Chl-Alt & med & -27.64 & 0.06 & 7.6 & & & & & & & & \\
\hline 114432 & Guadamur mine (waste) & Retrograded (supergenic) & Qtz-Kln-Gt-Jar-Alt & high & -27.78 & 0.04 & 7.8 & 26.50 & 3.360 & 0.071 & 1200 & 1580 & 15.83 & 0.02 & 0.05 \\
\hline 114433 & Guadamur mine (waste) & Retrograded (supergenic) & Qtz-Prl-Alt & high & -27.75 & 0.19 & 7.0 & 26.50 & 3.360 & 0.090 & 948 & 1579 & 16.07 & 0.02 & 0.05 \\
\hline \multirow[t]{2}{*}{114434} & Guadamur mine (waste) & Retrograded rock & Qtz-Ms-Ilm-Gt-Alt & high & -27.59 & 0.06 & 24.7 & 26.48 & 3.363 & 0.097 & 879 & 1581 & 16.07 & 0.10 & 0.05 \\
\hline & & & Mid-T deformed rocks & & & & & & & & & & & & \\
\hline 114554 & P. Montalbán mine & Cataclasite & Qtz-(Bt)-Pl-Alt & med & -23.15 & 0.02 & 2.2 & 26.49 & 3.362 & 0.103 & 828 & & & & \\
\hline 114555 & P. Montalbán mine & Milonite & Qtz-Ms-(Pl)-Cal-Alt & high & -23.03 & 0.30 & 4.4 & 26.50 & 3.361 & 0.082 & 1040 & & & & \\
\hline 114556 & P. Montalbán mine & Cataclasite & Qtz-Ms-(Bt)-(Pl)-Alt & med & -23.13 & 0.16 & 3.1 & 26.50 & 3.361 & n.d. & & 1579 & 18.17 & 0.06 & 0.15 \\
\hline 114557 & P. Montalbán mine & Cataclasite & Qtz-Ms-Cal-Alt & high & -23.01 & 0.24 & 5.8 & 26.45 & 3.367 & 0.106 & 805 & 1579 & 14.79 & 0.01 & 0.02 \\
\hline 114558 & P. Montalbán mine & Milonite & Qtz-Ms-(Bt)-(Pl)-(Grt)-Cal-Alt & med & & & 7.8 & 26.54 & 3.359 & n.d. & & 1579 & 16.83 & 0.03 & 0.10 \\
\hline 114635 & Guadamur mine & Hydrothermal vein & Cal & high & -5.15 & 0.001 & & & & & & & & & \\
\hline
\end{tabular}

rite, Kln= kaolinite, Jar= jarosite, Prl=

Pyrophilite, mostly after Kretz (1983). Alt= clay minerals; Alteration intensity: - (null), low (<10\%, mainly feldspars), medium (10-50\%, feldspars, cordierite, biotite), high $(>50 \%$ supergenic minerals). * = based in modal estimation 


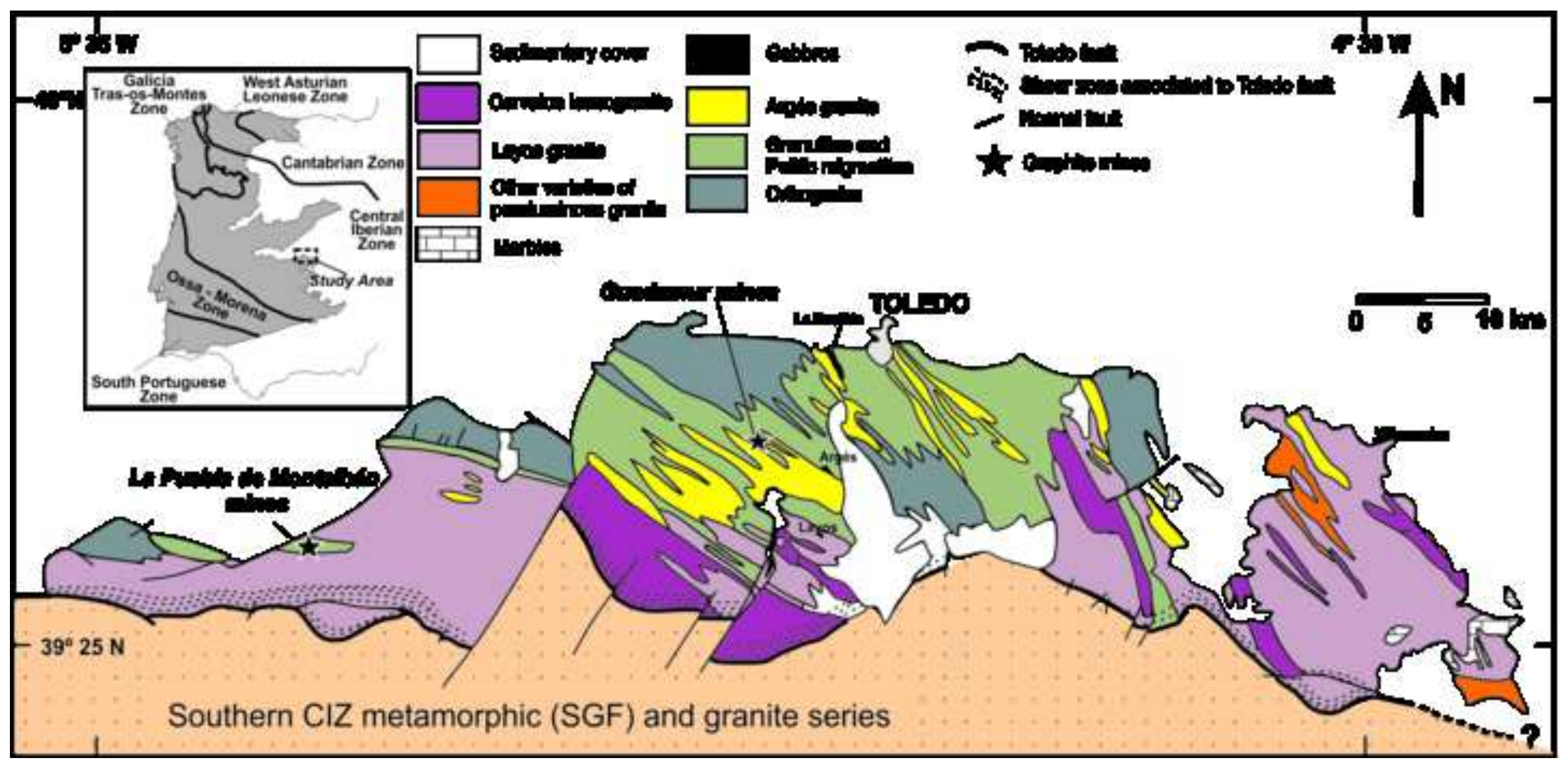




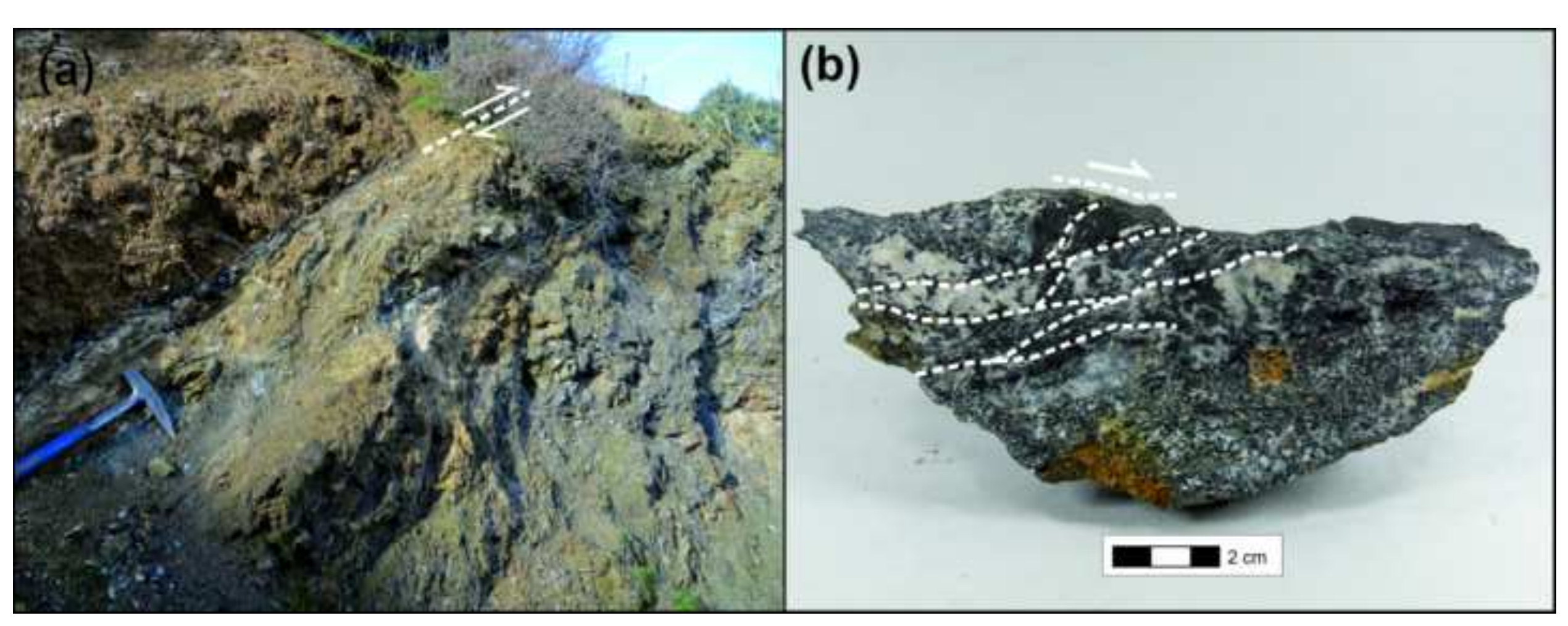



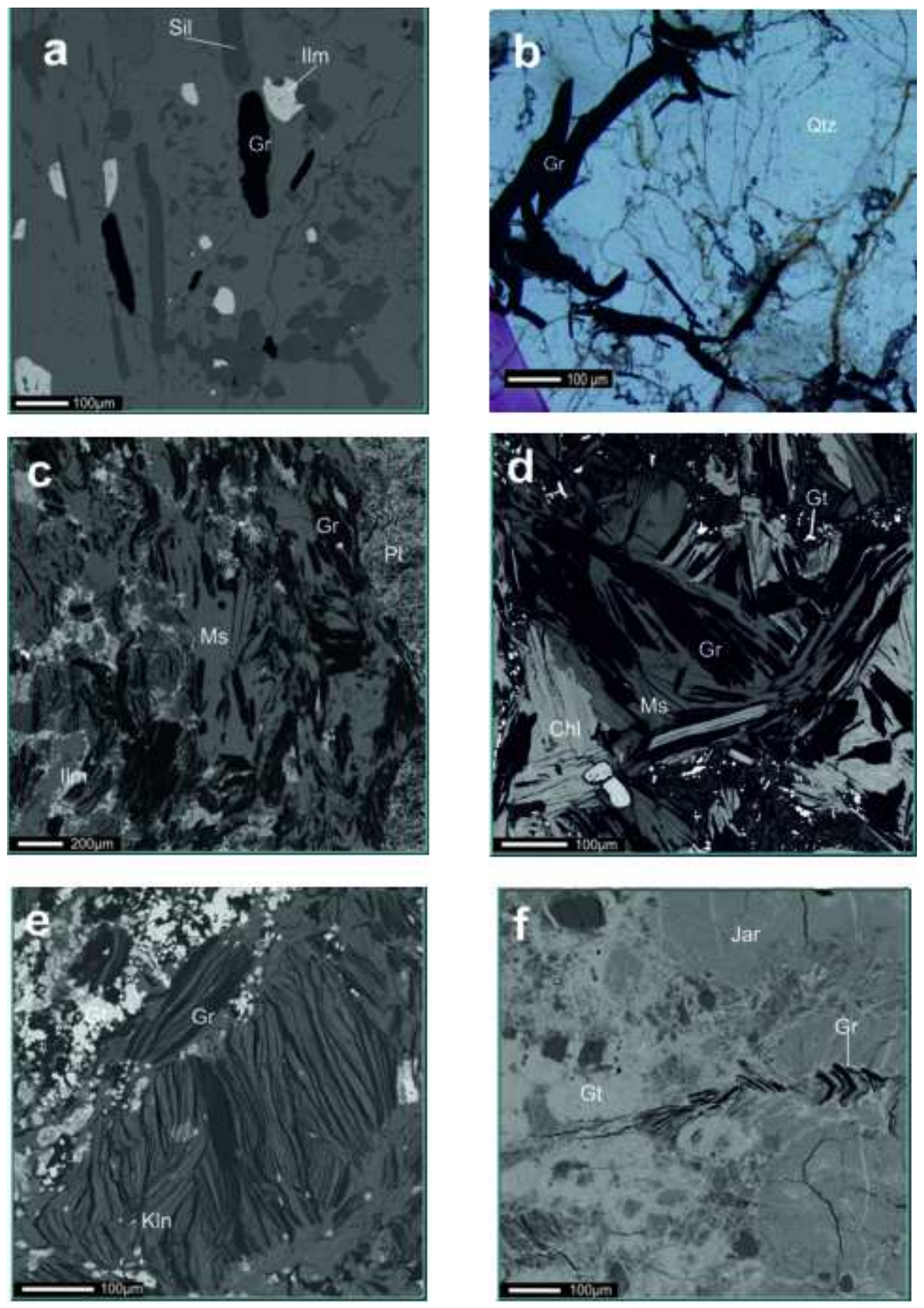

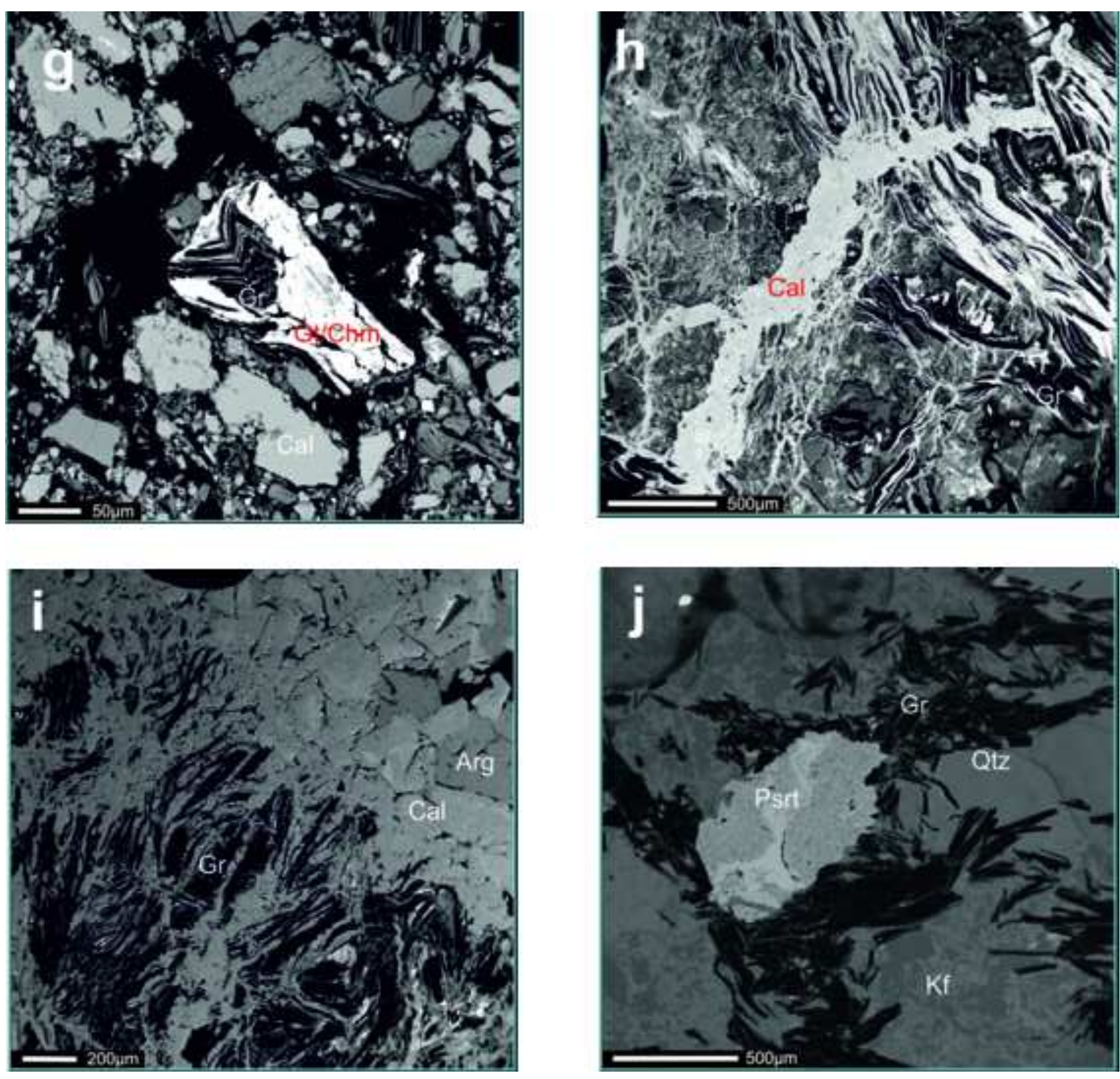

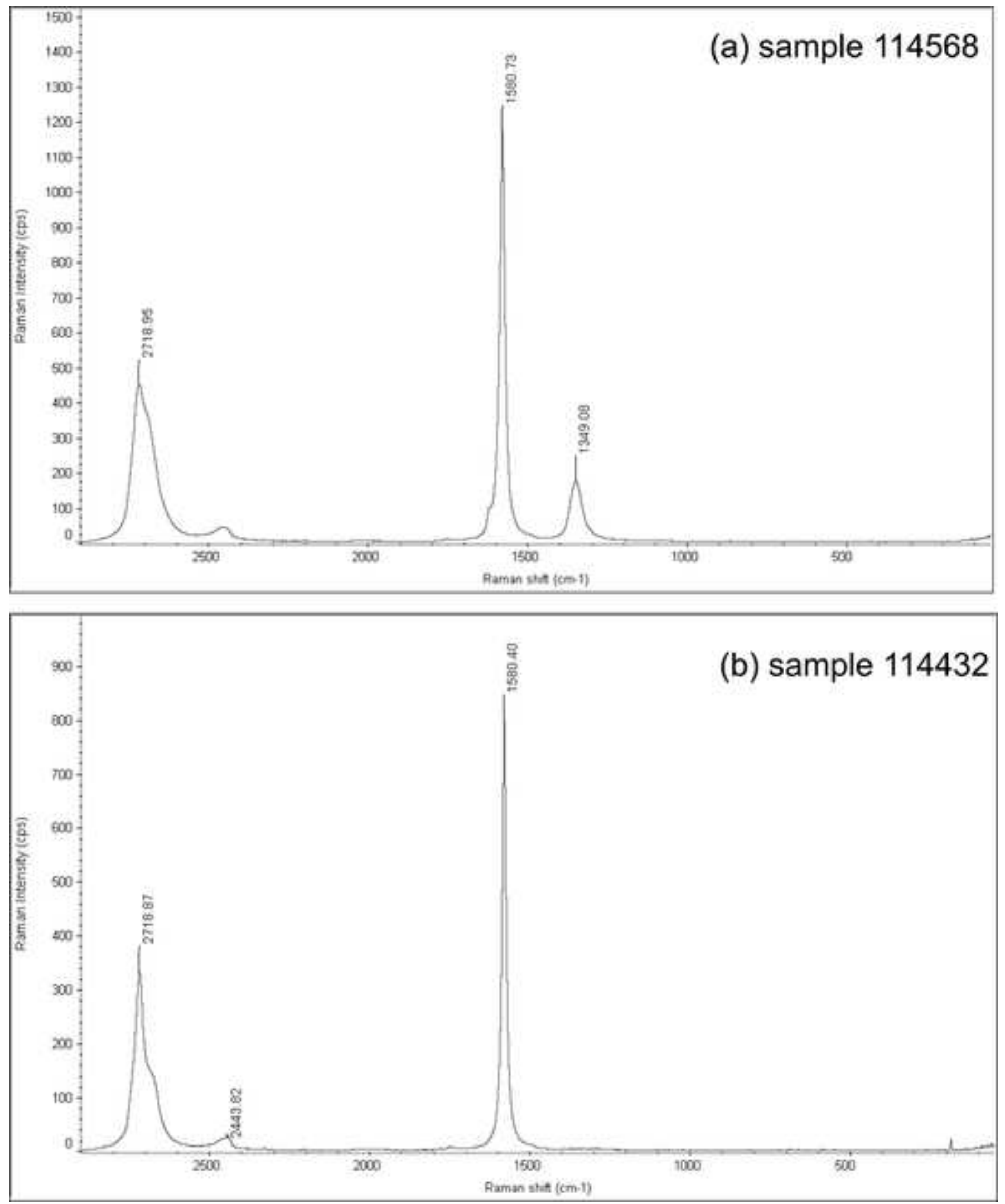


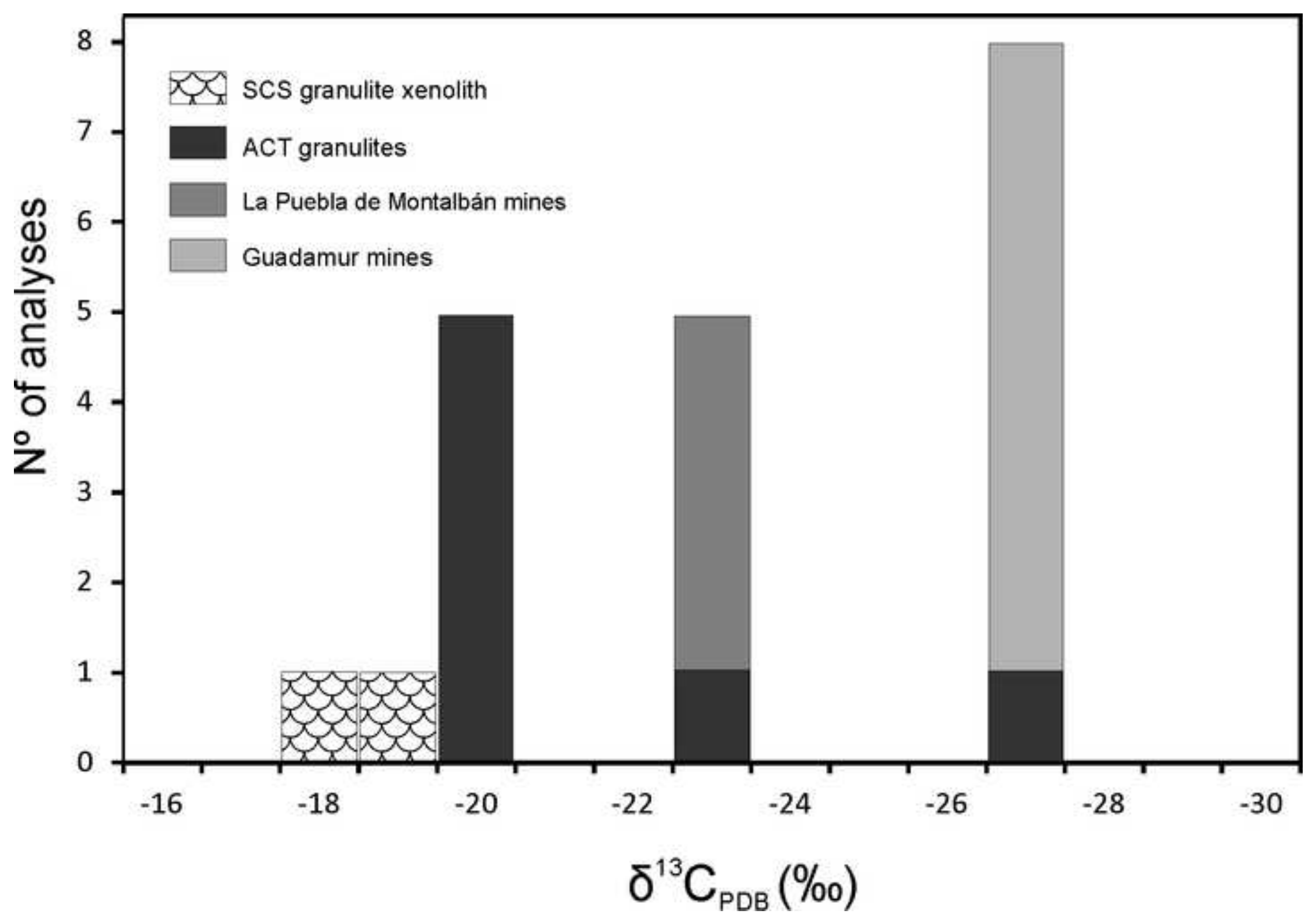




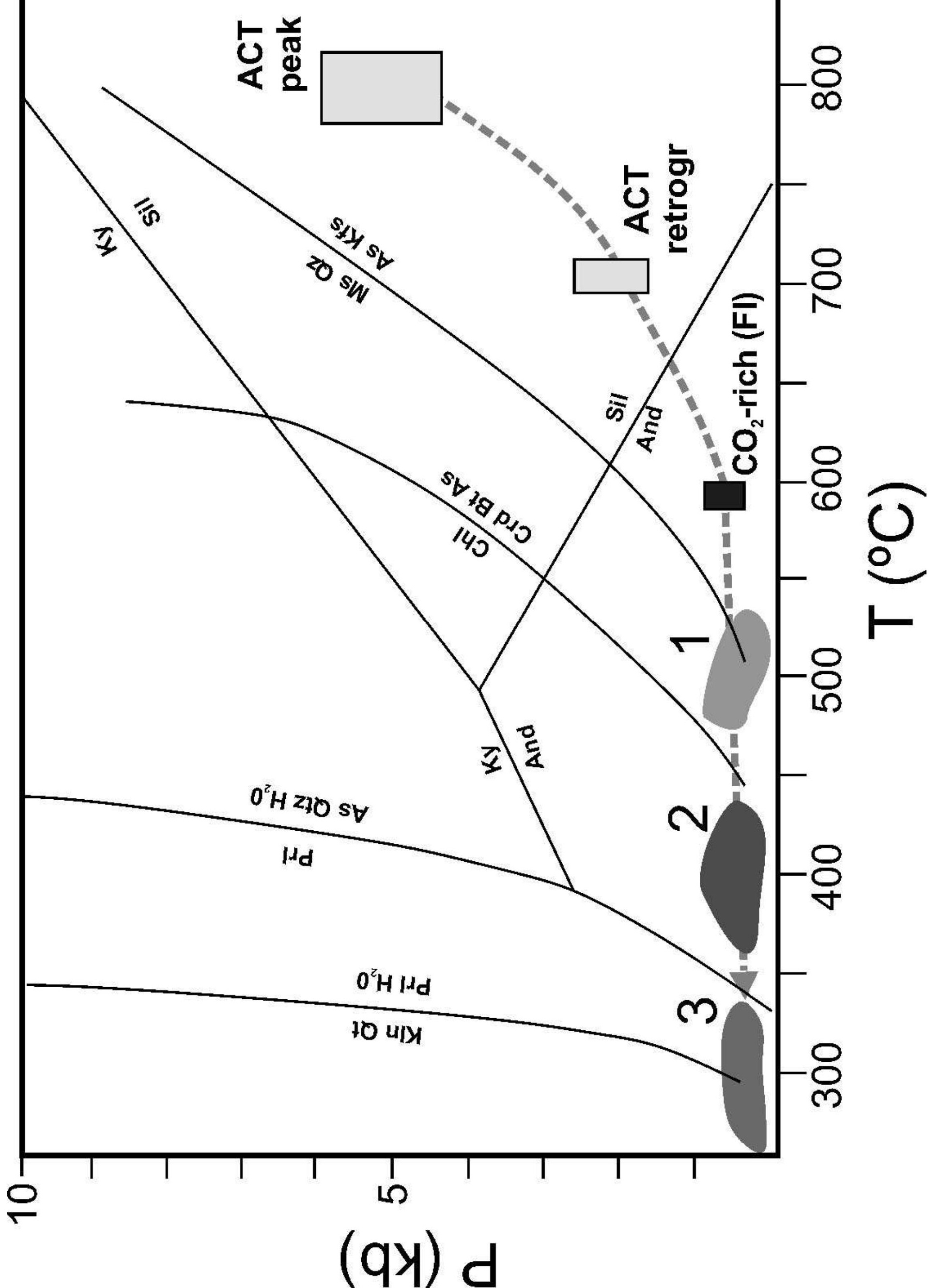




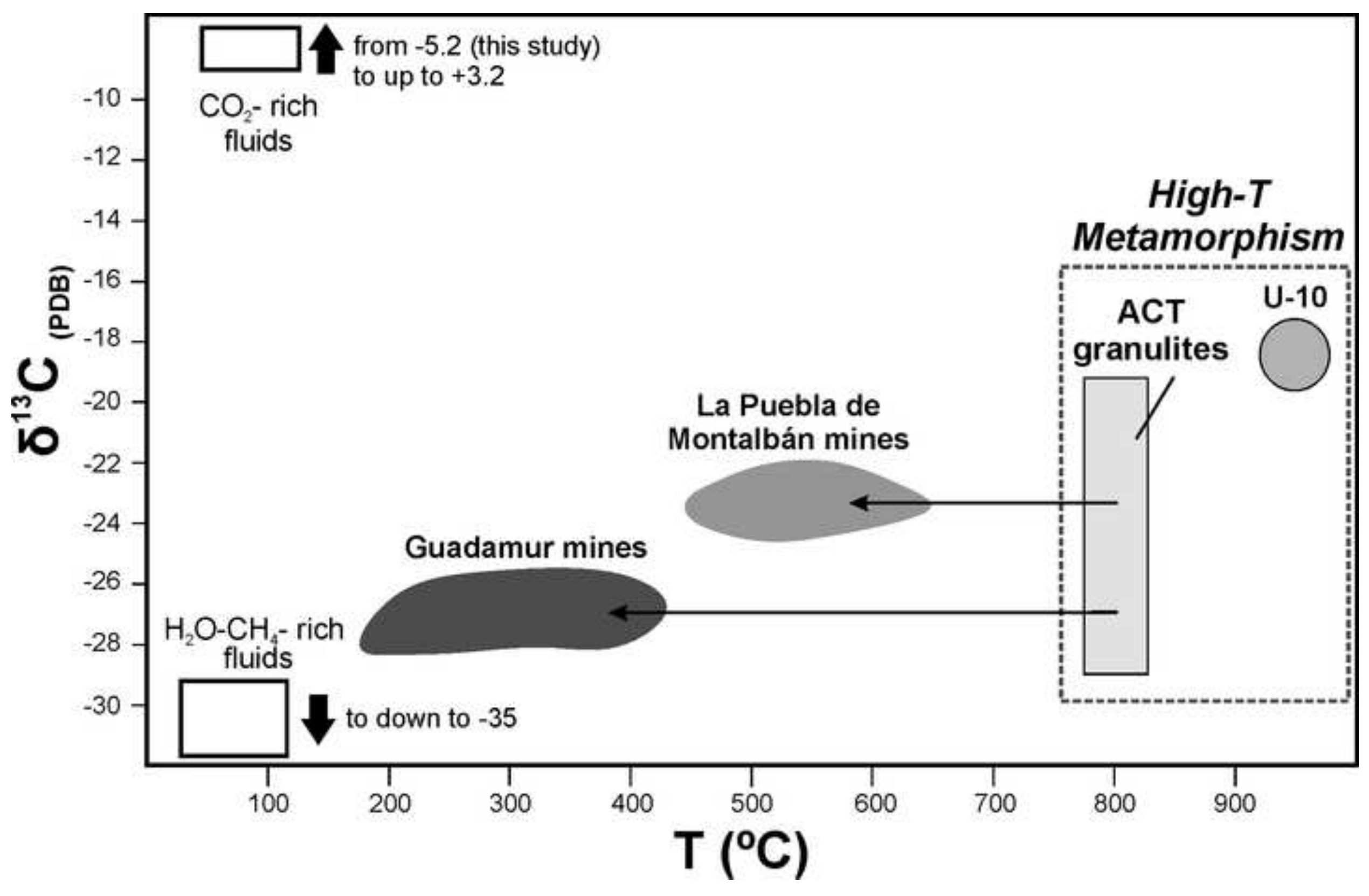

